\title{
Students' science process skills and interpersonal intelligence in biology learning using guided inquiry
}

\author{
N. Nopiya a,1,*, Anna Fitri Hindriana a,2, Sulistyono a,3 \\ a Biology Education Study Program, Universitas Kuningan, Jl. Pramuka No.67 Kuningan, West Java 45512, Indonesia \\ 1 nopiyabiologic@gmail.com *; 2 anna@uniku.ac.id ; ${ }^{3}$ sulistyono@uniku.ac.id \\ ${ }^{*}$ Corresponding author
}

\begin{tabular}{|c|c|}
\hline ARTICLE INFO & ABSTRACT \\
\hline $\begin{array}{l}\text { Article history } \\
\text { Received December 17, } 2020 \\
\text { Revised February 25, } 2020 \\
\text { Accepted March 18, } 2020 \\
\text { Published March } 31,2020 \\
\text { Keywords } \\
\text { Science process skills } \\
\text { Guided inquiry } \\
\text { Interpersonal intelligence }\end{array}$ & $\begin{array}{l}\text { Teacher-centered learning has no ability in empowering students' science process skills } \\
\text { and interpersonal intelligence. This study aimed at analyzing the effect of guided inquiry } \\
\text { on students' Science Process Skills (SPS) and Interpersonal Intelligence (II). This } \\
\text { quasi-experiment used nonequivalent control group design. This study involved control } \\
\text { and experimental classes of eleventh graders in biology class in which the material } \\
\text { learnt was respiratory system. The SPS data was collected using test instrument, } \\
\text { whereas the II data was gained using observation sheet. The analysis results informed } \\
\text { that the students who joint the guided inquiry class possessed the better competencies, } \\
\text { both in their SPS }(p=0.04) \text { and II }(p=0.001) \text {. Therefore, the guided inquiry significantly } \\
\text { contributes toward the improvement of students' SPS and II. The findings of this } \\
\text { research can be the considerable information to creat the learning which } \\
\text { accommodates students' SPS and II. } \\
\text { This is an open access article under the CC-BY-SA license } \\
\text { a }\end{array}$ \\
\hline $\begin{array}{l}\text { cite: Nopiya, N., } \mathrm{H} \\
\text { biology learr } \\
10.22219 / \mathrm{jpb}\end{array}$ & $\begin{array}{l}., \& \text { Sulistyono, S. (2020). Students' science process skills and interpersonal intelligence } \\
\text { led inquiry. JPBI (Jurnal Pendidikan Biologi Indonesia), 6(1), 123-134. doi: https://doi.o }\end{array}$ \\
\hline
\end{tabular}

\section{INTRODUCTION}

Problems faced at State Senior High School (SMAN) 1 of Jamblang based on the results of grade XI observations indicate that the learning process is still experiencing some problems, both internal and external, such as teacher-centered learning so that student involvement becomes less that results in students becoming passive. Other problems faced at the State Senior High School (SMAN) 1 of Jamblang based on the results of direct interviews are the weak learning process so that it results in low comprehension of students, a lack of communication so that there is no exchange of information between groups, and low level of student learning abilities because it is not trained in their daily lives to foster the ability to work together among students. This can be seen from the passive behavior of students in the class when given time to discuss and answer questions verbally. They do not want to be open when communicating and do not wish to accept suggestions and criticisms from friends.

In connection with the problems above, it is necessary to establish a more valuable learning innovation. The expected innovation is not only in the form of a collection of facts, concepts, principles, or processes of discovery, but also further development in applying them in everyday life. Learning must be directed to search 
for information and do an action so that it can help students to gain deeper concepts. Therefore, learning must emphasize the involvement of direct experiences that are student-centered. This innovative learning process is expected to increase skills both in the science process and interpersonal intelligence. That the inquiry learning model trains students to apply concepts referring to the problem formulation so that the interpretation of the data collected is more directed (Jerrim, Oliver, \& Sims, 2019; Luijk, Kruger, Zijlstra, \& Volman, 2019; Yudarwati, 2019). The guided inquiry learning model could train multiple intelligences to improve students' interpersonal intelligence abilities (Ebert, Mollart, Nolan, \& Jefford, 2020; Metcalf et al., 2018; Wang \& Jou, 2016).

Research on process skills has been carried out in the United States of America (Lawless, Brown, Rhoads, Lynn, \& Newton, 2018), and in the Netherlands (Stouwe, Asscher, Hoeve, Laan, \& Stams, 2018). Research on Science process skills in California (Linnell et al., 2013), and in Kenya (Abungu, Okere, \& Wachanga, 2014). Research on interpersonal intelligence has been carried out in Spain (Rey \& Extremera, 2014), in the United States (Murphy \& Hall, 2011), and in Mexico (Romero, Berrocal, Estrada, \& Guajardo, 2017). Inquiry research on science in Washington (Teig, Scherer, \& Nilsen, 2018), and inquiry on environmental subjects in Spain (Michos \& Leo, 2020). Research on guided inquiry has been widely carried out in the United States of America (Roller \& Zori, 2017), and in Canada (Cotton, 2009). Guided inquiry research in science subjects in Turkey (Ucar \& Trundle, 2011), and in Taiwan (Wen et al., 2020). But there is no research on science process skills and interpersonal intelligence in biology learning using guided inquiry so that the novelty of this study is the use of guided inquiry to develop the ability of science process skills and interpersonal intelligence in biology subjects.

Based on this, it can be seen that research on science process skills and interpersonal intelligence in biology learning using guided inquiry is the first and important research to do. The results of this study will provide information on how guided inquiry in learning biological material can develop students' science process skills and interpersonal intelligence abilities. The results of this study certainly also provide information on how to implement guided inquiry learning in biological material to develop science process skills and interpersonal intelligence. Based on the benefits of the research results, this research is very important to do, so that education in Indonesia can mimic and modify this research activity in order to develop students' scientific process skills and interpersonal intelligence abilities. Armed with the ability of science process skills and interpersonal intelligence is needed by students in Indonesia to be able to compete in the current 4.0 industrial revolution era.

In this study, the author chooses the guided inquiry learning model to be applied in the learning process by employing a variety of supporting strategies, methods, media, and learning resources. This study was chosen with the consideration that the research will be conducted on students of grade XI of State Senior High School (SMAN) 1 of Jamblang Cirebon, where the level of cognitive development of students is still at the stage of learning the scientific process. The linkage of the guided inquiry learning model in improving students' science process and interpersonal intelligence abilities is reflected in the learning process contained in the syntaxes of the guided inquiry learning model. This learning process emphasizes the scientific approach, in which this scientific approach becomes the bridge for the development of students' attitudes, skills, and knowledge. This study aimed at analyzing the effect of guided inquiry on students' science process skills and interpersonal intelligence.

\section{METHOD}

This study was conducted at SMAN 1 of Jamblang, Cirebon Regency with the object of grade XI.5 of Science students as the experimental class and grade XI.6 of Science students as the control class. The method used in this study is the experiment, and the type of research is the quasi-experiment. The research design used is the Non-equivalent Control Group Design model. The population in this study were all students of Grade XI of Science of SMAN 1 of Jamblang. The sample was determined randomly by collecting research data using the non-probability sampling method with a purposive random sampling technique. The research instrument used in this study was in the form of an observation sheet of the implementation of Guided Inquiry Learning model, test item description, observation sheet of interpersonal intelligence rubric, and questionnaire. To analyze the data, the qualitative data were analyzed descriptively to find trends that arise in the study. While the quantitative data were analyzed by statistical tests. The statistical data processing is performed using SPSS 16.0 for Windows and Microsoft Excel 2007. The material used is the respiratory system in humans.

The study begins by identifying problems with learning biology in schools that will serve as research sites by reviewing empirical and theoretical data. Empirical data were obtained from various references, while theoretical data was obtained by looking at teacher learning while teaching the class. The data collection stage in this study is for the implementation of the guided inquiry learning model when data is collected during the 
learning process based on observer data sources, for the science process skills data is collected at the time before and after learning based on student data sources, for interpersonal intelligence students are collected data at the time the learning process is based on observer data sources and for student questionnaire responses the data is collected at the time after the learning process data sources from students.

\section{RESULTS AND DISCUSSION}

An observer previously made observations on the implementation of the guided Inquiry learning model to monitor the implementation of the learning model from the beginning to the end of the learning process. The results of the record of the activities carried out by the teacher in the learning process using the guided Inquiry learning model are described in the data of the Table 1.

Table 1. Percentage of teacher observation results using the guided inquiry learning model

\begin{tabular}{|c|c|c|c|c|c|c|c|}
\hline \multirow[b]{2}{*}{ No } & \multirow[t]{2}{*}{ Observed Aspects } & \multicolumn{3}{|c|}{ Observer } & \multirow[b]{2}{*}{ Average } & \multirow[b]{2}{*}{ Percentage (\%) } & \multirow[b]{2}{*}{ Note } \\
\hline & & 1 & 2 & 3 & & & \\
\hline \multirow{2}{*}{1} & Preliminary Activity & 3.75 & 3.75 & 3.5 & 3.7 & 91.7 & Excellent \\
\hline & & & & & 3,7 & 91.7 & Excellent \\
\hline \multirow{8}{*}{2} & Core Activity & & & & & & \\
\hline & Introduction & 2 & 3.5 & 3 & 2,8 & 71 & Good \\
\hline & Questioning & 3 & 4 & 3 & 3,3 & $83 ., 3$ & Excellent \\
\hline & Planning & 4 & 4 & 4 & 4 & 100 & Excellent \\
\hline & Implementing & 3.7 & 3.3 & 3.3 & 3.4 & 86 & Excellent \\
\hline & Conclusing & 4 & 4 & 4 & 4 & 100 & Excellent \\
\hline & Reporting & 4 & 4 & 4 & 4 & 100 & Excellent \\
\hline & & & & & 3.6 & 90 & Excellent \\
\hline \multirow{3}{*}{3} & Closing Activity & 3.7 & 4 & 4 & 3.9 & 97.2 & Excellent \\
\hline & & & & & 3.9 & 97.2 & Excellent \\
\hline & & & & & 3.7 & 93 & Excellent \\
\hline
\end{tabular}

Based on the table above, it can be explained that the implementation of learning using the guided Inquiry learning model has been implemented by the teacher very well. This is marked by the application of all indicators of the syntax of the guided inquiry learning model by the teacher with an average percentage of the implementation of the preliminary activity of $91.7 \%$, the implementation of the core activity of $90 \%$ and the application of the closing activity of $97.2 \%$. Of the three steps of the learning process, the average total implementation of the learning process is $93 \%$, with a very good category. This is because the teacher can facilitate student activities well.

The implementation of learning by using the guided inquiry learning model related to the Learning Implementation Plan prepared before the learning activities are carried out. The first step taken in the learning process is the preliminary activity. In the preliminary activity, to start the lesson, the teacher makes apperception and motivation about the learning material, which is the danger of cigarette contents towards health and the frequency of breathing. The activities to start the learning process at each meeting is different. The teacher has done the activities of beginning the lessons. In the opening activity at the first meeting, to attract the attention of students, the teacher uses teaching media that is displaying a warning picture of danger on cigarette packs.

The students' responses regarding the media showed that they were very concerned about the warning display of cigarette packs and left all other activities, such as those who had been chatting suddenly paid attention quickly and quietly to what the teacher explained in front of the class. The media is very important to help students understand the learning material. Therefore, the role of the media in the learning process becomes important because it will make the learning process more varied and not boring. The existence of learning media as a tool in the learning process is a fact that cannot be denied. The teacher as a messenger has a great importance to facilitate his task in conveying messages or learning material to students. In the second meeting, the teacher started the lesson by looking at pictures of people with light activities and people with strenuous activities. In responding to the pictures, the students are very curious so they are more interested to prove the frequency of breathing based on different activities. The students' response to the image raises a question of one of the students stating, "Ma'am, what causes the frequency of human breathing to be different?". Learning strategies used by teachers in the use of image media are included in the contextual strategy, in which the students can connect the knowledge they have with their daily lives from these media images. According to Gillies and Rafter (2020) that a contextual approach is a learning model where the teacher must bring real-world situations into class and encourage students to make the relationship between knowledge by applying it deeply in their lives as family members and society. 
The second activity of the preliminary activities is fostering motivation. The activity is generated through questions that can affect the students' learning motivation. In the learning activities, the author raises student motivation by asking questions related to the hazard content of cigarettes for health to arouse students' curiosity in learning activities, which is "What is the meaning obtained from pictorial warnings on cigarette packs?" Answers and responses from the teacher's question are varied, such as cigarettes can cause dangerous diseases, then the teacher confirms the answers to questions asked to students. This question is asked as a motivation to stimulate student knowledge before the beginning of the learning process. The strategy used in the activity raises motivation, which is the argumentation strategy in which the teacher directs students to argue, such as making claims and explaining the reasons. One of the examples of students' answer is that cigarettes can cause a dangerous disease. The teacher guides students to be able to give reasons for the answers because cigarettes contain substances that are harmful to the body, causing interference with the respiratory organs. Based on these activities, following the theory put forward by Eskin and Bekiroglu, (2013), it is stated that the argumentation as a learning strategy has been investigated for its effect on learning. Another activity at the beginning of the lessons allows the teacher to conduct activities to provide a reference. This activity is defined as an activity or effort to give an overview to students about the things to be learned as well as the ways to be taken in the core activities of the learning process.

The second aspect is the core activities. The achievement of the results of these core activities occurs because researchers have been able to carry out core activities well, especially in the aspects of planning, conclusion, and reporting. In the aspect of planning, the teacher guided students in planning experiments. In this activity, the teacher divides students into six heterogeneous groups. This is to facilitate students' interpersonal communication by training them to communicate with others and be able to collaborate with teams. This is supported by the opinion of Zhang (2019), which explains that student worksheets are student guides that are used to carry out the investigation or problem-solving activities.

Characteristics of guided inquiry-based worksheets used include the syntax of the learning model consisting of 6 stages, which are introduction, questioning, planning, implementation, conclusion, and reporting. This guided inquiry-based worksheet is composed by applying the guided inquiry learning model, which requires students to learn more by themselves and develop activeness in problem-solving. This opinion is supported by Nenadal and Mistry (2018), who states that students' worksheets with the guided inquiry method can help students to more easily understand learning material and can provide direct learning experiences to them. This guided inquiry-based worksheet can be used by students as a learning medium to support them in learning activities. The questions contained in the sheet associated with the experiments conducted.

The next stage is the conclusion. The teacher guides students to conclude the material they have learned. In the conclusion stage, the teacher guides students to find from the results of their research by analyzing the data obtained from the inquiry process. Based on the data analysis, students are guided by the teacher to compare the truth of the results of research with the initial hypothesis. This opinion is supported by the opinion of Birren and Kieboom (2017), which states that the interpretation of data means explaining the data themselves. Students can make simple comparisons or look for patterns to interpret data. In concluding, students must compare the results of interpretation data with the hypotheses they made at the beginning of the experiment. Based on the previous explanation, the next step leads the students to decide whether the hypothesis is true or false. This step is called concluding. This conclusion is facilitated by the guided inquirybased worksheet, which allows students to take lessons from the learning process in the form of value claims and knowledge claims.

The last stage of the guided inquiry learning model is reporting, in which the teacher directs students to present the results of their experiments in front of the class. This reporting process facilitates the development of students' interpersonal intelligence as well. For example, students openly express their opinions and report findings from the results of the investigation about the material. However, the teacher directs the course of presentations and discussions to lead to learning objectives. Inquiry learning is given the opportunity for students to develop their skills needed in daily life. The teacher acts as a motivator, facilitator, and mediator in the learning process.

The last aspect is the closing activity. The closing activity consists of reviewing and evaluating. The teacher has done the activity of closing the lesson in the implementation of the learning process with the guided inquiry learning model. In the reviewing activity, the strategy used is the teacher guiding one student to conclude the material that has been learned. The ability of students shows that they can conclude learning material that the content contained in a cigarette can damage respiratory organs such as the lungs. The harmful contents in cigarettes include nicotine, tar, carbon monoxide, and formalin. The second aspect of the closing activity is evaluating. Evaluating means checking whether the material presented is acceptable to students or not. This activity should be distinguished from the evaluation activities for the report card filling materials. The teacher gives an evaluation of the material that has been given. The teacher guides the students in evaluating the 
content that has been learned by using a talking stick accompanied by a song. Then, when the song stops and the stick is on one of the students, the student will get questions from the stick. Students' response at the evaluation activity shows that they sternly answer the questions in the stick.

Improved results of students' science process abilities (Kemampuan Proses Sains or KPS) that are applied with the guided Inquiry learning model by using a scientific approach can be seen as followed. The results can be seen from the initial test (pre-test) and final test (post-test). The average pre-test-post-test between the experimental class and the control class can be seen in Figure 1.

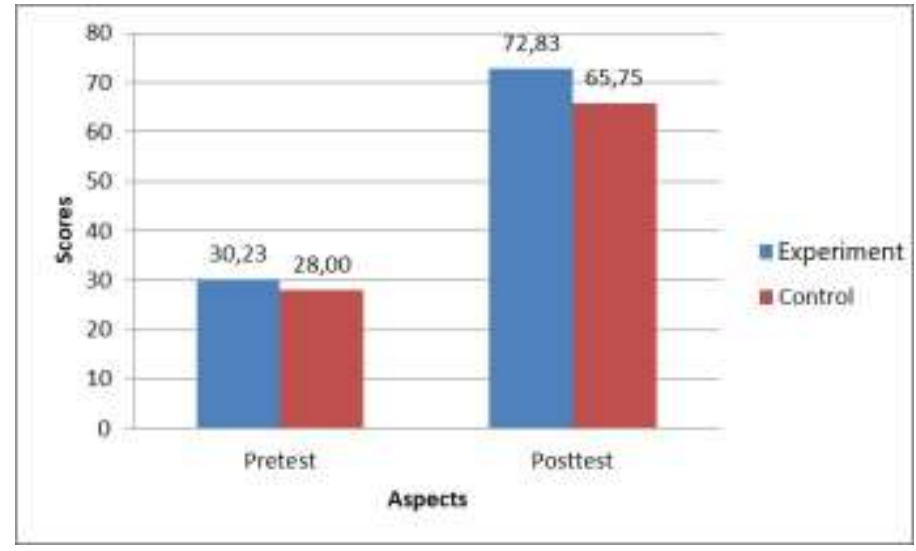

Figure 1. Graph of the average pre-test-post-test science process ability value of students

Figure 1 shows the average acquisition of KPS pre-test and post-test values between the experimental class and the control class. The average pre-test value of the experimental class and the control class showed differences. The average pre-test value of the experimental class was 30.23 , while the average pretest value of the control class was 28.00. The average data of the N-gain of KPS value of the experimental class and the control class can be seen in Figure 2.

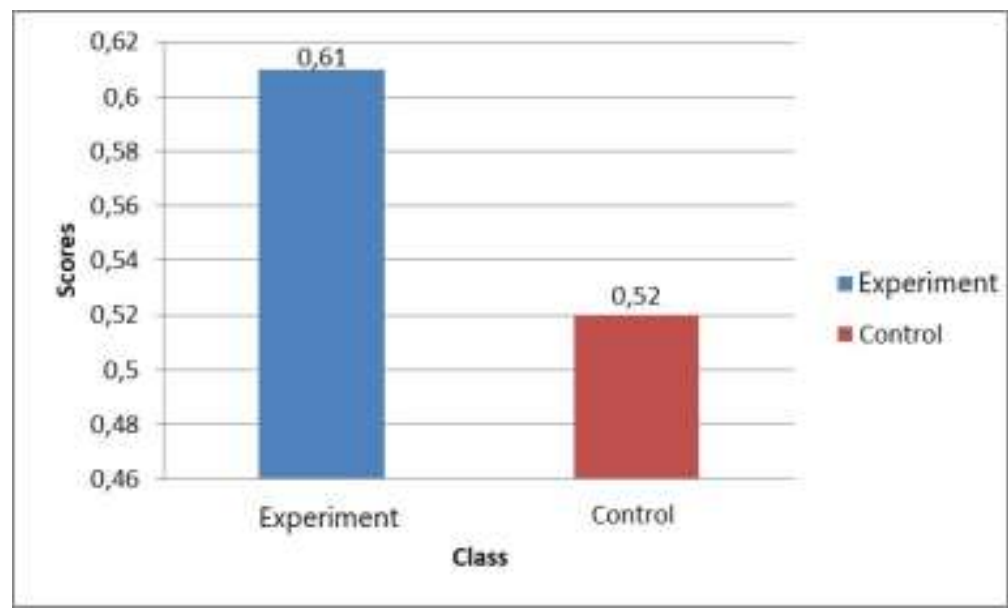

Figure 2. Graph of the average N-Gain score of KPS of students

Figure 2 shows the average N-Gain of KPS value of the experimental class and the control class. Both the average N-Gain value of the experimental class and the control class was included in the medium category. The average $\mathrm{N}$-gain value of the experimental class was 0.61 , and the average $\mathrm{N}$-gain value of the control class was 0.52 . Comparison of the value of the pre-test conducted before learning and the post-test conducted after learning using the guided inquiry learning model for each indicator of science process abilities (KPS) in the experimental class and the control class can be seen in Figure 3 (KPS 1 is control variables, KPS 2 is formulate the hypothesis, KPS 3 is experiment, and KPS 4 is data linterpretation).

Figure 3 shows a graph of the average pre-test and post-test scores of each indicator of students' science process abilities in the experimental class and the control class. The average pre-test score of the experimental class showed that the average indicator of the greatest science process was the skill of formulating a hypothesis (KPS 2). The lowest average pre-test score was shown in the controlling skill (KPS 1) variable. The average value of the control class pre-test showed that the greatest value was the indicator of experimental skills (KPS 3), while the indicator of controlling skills (KPS 1) variable shows the lowest value. 


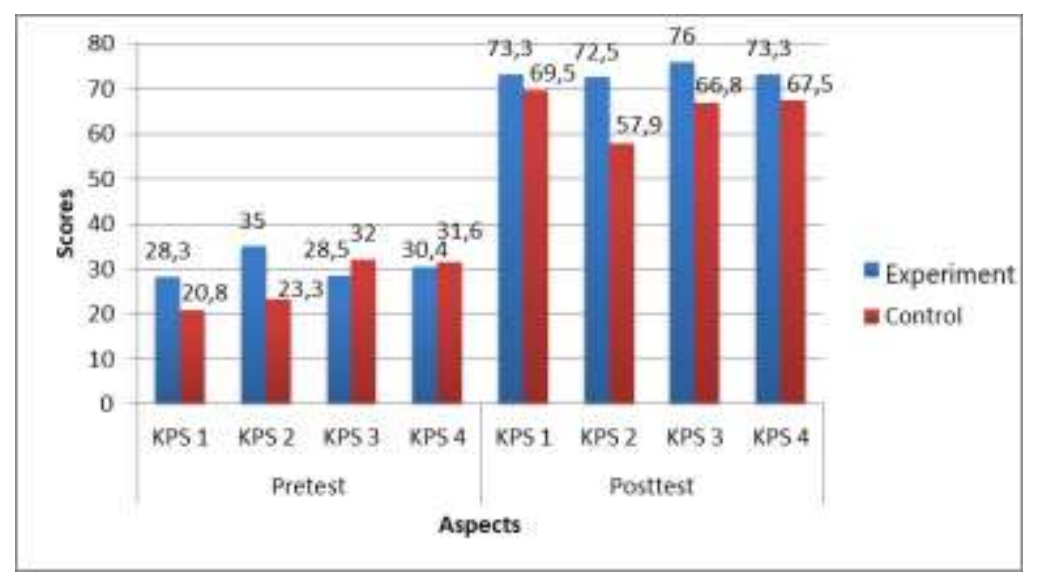

Figure 3. Graph of the average pre-test-post-test value of each indicator of KPS of students

The difference in the increase in the ability of the science process abilities of the experimental class and the control class can be known by conducting statistical tests. The statistical test used in this study was carried out through two stages, consisting of the prerequisite test and the different tests. The prerequisite test consists of a normality test conducted with the Kolmogorov-Smirnov test and a homogeneity test, in which both tests are conducted to determine whether the data obtained from the results of the study are normally distributed and homogeneous or not. The series of statistical tests in this study were carried out using SPSS 16 software.

Statistical tests were conducted to determine differences in the science process abilities of the experimental class and control class students. The results of the prerequisite test differences in KPS students of the experimental class and the control class are explained in the following Table 2.

Table 2. Prerequisite test results

\begin{tabular}{llllll}
\hline \multirow{2}{*}{ Class } & \multirow{2}{*}{ Data } & Normality Test & \multicolumn{2}{c}{ Homogeneity Test } \\
\cline { 3 - 6 } & Sig. & Information & ig. & Information \\
\hline Experiment & Pre-test & 0.54 & Normal & 0.133 & Homogen \\
\multirow{2}{*}{ Control } & Post-test & 0.98 & Normal & & \\
& Pre-test & 0.25 & Normal & 0.124 & \\
& Post-test & 0.99 & Normal & & \\
\hline
\end{tabular}

Table 2 presents the results of the normality test and the homogeneity test. Based on the results of the normality test of the experimental class and the control class, it showed that the data were normally distributed because the significance value was greater than 0.05 . Based on these data, it can be concluded that the experimental and control classes (pre-test and post-test) are normally distributed. Homogeneity test results also showed homogeneous data in the experimental class because of the sig value. $0.133>0.05$, as well as the control class sig. $0.124>0.05$. Based on the prerequisite test results, it is known that the data in both classes are normally distributed and homogeneous.

Based on the prerequisite test results that show that the data is normally distributed and homogeneous, then the different tests conducted on the data is the Parametric Pair Two Sample Difference test (T-test), which can be described according to Table 3.

Table 3. General pre-test-post-test results

\begin{tabular}{|c|c|c|c|c|}
\hline Class & Data & Differential test & Sig. (2-tailed) & Note \\
\hline $\begin{array}{l}\text { Experiment } \\
\text { Control }\end{array}$ & Pre-test & Statistic parametric (T-test) & 0,00 & $\begin{array}{l}\text { Significantly } \\
\text { different }\end{array}$ \\
\hline $\begin{array}{l}\text { Experiment } \\
\text { Control }\end{array}$ & Post-test & Statistic parametric (T-test) & 0,04 & \\
\hline
\end{tabular}

Table 3 shows the different test results from the pre-test-post-test data in general. The significance value based on the results of the T-test is 0.004 and 0.000 (pre-test and post-test), which means that $\mathrm{Ho}$ is rejected and $\mathrm{Ha}$ is accepted. Based on these data, it can be concluded that there is a difference in the increase in KPS between the experimental class using the guided inquiry learning model and the control class using the learning model of discussion and lecture. 
For the post-test results in the experimental class, it obtained the experimental indicator (KPS 3) with the highest score, while the indicator with the lowest score is formulating a hypothesis (KPS 2). The highest experimental indicator acquisition (KPS 3) is because, in this experiment indicator, students' ability to investigate has a high curiosity and has a thorough observation of their practicum activities; they conduct experiments by being directly involved in practicum activities. This third indicator is facilitated in the syntax of guided inquiry. The implementation allows the teacher to ask students to solve problems through investigation then supervising and guiding student activities to develop their curiosity so that they can form science process abilities by conducting experiments directly equipped with worksheets based on guided inquiry-based students worksheet in which there are work steps that make it easier for students to conduct experiments.

This is in accordance with the opinion of Abungu et al (2014), who stated that when students conduct experiments, then they will practice their process skills and abilities. This is consistent with the opinion of Makar, Ali, and Fry (2018), stating that the main emphasis of the guided inquiry learning model lies in the ability of students to search and find answers to problems given by using their skills, while the teacher acts as a facilitator and guide students during learning activities. Thus, this inquiry learning is considered to help students to construct concepts learned through process skills. Research conducted by Hong et al (2019) also states that the guided inquiry learning model can improve students' science process abilities. This is because students are directly involved in experimental activities, thus practicing their experimental abilities.

The lowest indicator is formulating a hypothesis (KPS 2). Because the ability of students to formulate a hypothesis could not reach the main goal of the learning process, so the teacher limits the formulation of the hypothesis so as not to leave the learning material. This hypothesis formulation learning activity is facilitated in the questioning syntax in how the teacher guides students to formulate the problem to be solved together. The technique allows the students to write problems that they think are important to solve together on the blackboard. Later, with the teacher's guidance, the student is directed towards which problem refers to the learning objectives so that a question is generated, which can be resolved by way of investigation. The acquisition of indicators for formulating hypotheses (KPS 2) of the experimental class is superior to the control class. This is because one of the guided inquiry phases used in the experimental class supports the skill of formulating hypotheses. The intended phase is the questioning stage. This is consistent with the results of research by Hindriana (2016), who state that this stage trains students to develop the hypothesized abilities given to LKPD. Students are required to provide hypotheses for a problem.

The next indicator is the controlling variables (KPS 1). The experimental class is superior to the control class because, in the experimental class, the students' ability is seen in the skills to determine the right variables and steps for the best solution. The increase is caused by one of the guided inquiry phases used in the experimental class, facilitating the control variable. The intended stage is the Introduction stage. This stage trains students in a way the teacher shows a video of the dangers of smoking in front of the class at the first meeting and shows a picture of the difference in respiratory frequency at the second meeting. This opinion is supported by the results of Connors (2019), which states that students who use guided inquiry learning model are easier to interpret observations than students with direct learning. Whereas in the control class, the learning process does not conduct experiments, so it is difficult to determine the variables in this indicator.

The last observed KPS indicator is interpreting data. The experimental class obtained a greater value than the control class because this indicator is related to the ability of students to analyze the data obtained and interpret the data in the graph and answer with questions available in the guided inquiry-based worksheet. This indicator is facilitated by the syntax conclusion by means of the teacher giving the opportunity for students to discuss the results of the experiment so as to find ideas from ongoing learning concepts. This opinion is supported by the results of research by Roller and Zori (2017), who states that the inquiry learning model trains students in applying concepts referring to the problem formulation so that the interpretation of the resulting data is more directed.

Learning by lecturing and discussion methods in the control class lacks training in the science process abilities of students because, in the learning process, there are some skills that do not emerge, consisting of formulating problems, compiling hypotheses, and controlling variables. Students are only given ample opportunity to do flow card compilation and make conclusions. The usual method applied is less able to train science process skills optimally. Based on the explanation above, it is proven empirically and theoretically that students who learn with guided inquiry learning models can improve students' science process abilities.

The interpersonal intelligence indicators used in this study are the indicator of interpersonal intelligence. The interpersonal intelligence indicators observed are: 1) the process of someone responding to something; 
2) give feedback; 3) find answers and questions. Indicators used in interpersonal intelligence have passed the instrument trials and adjusted to the learning process in class. Interpersonal intelligence measurement is assessed through observation sheets with scoring rubric instruments. The results of the percentage value of each indicator of the interpersonal intelligence of the experimental class and control class students can be seen in Figure 4.

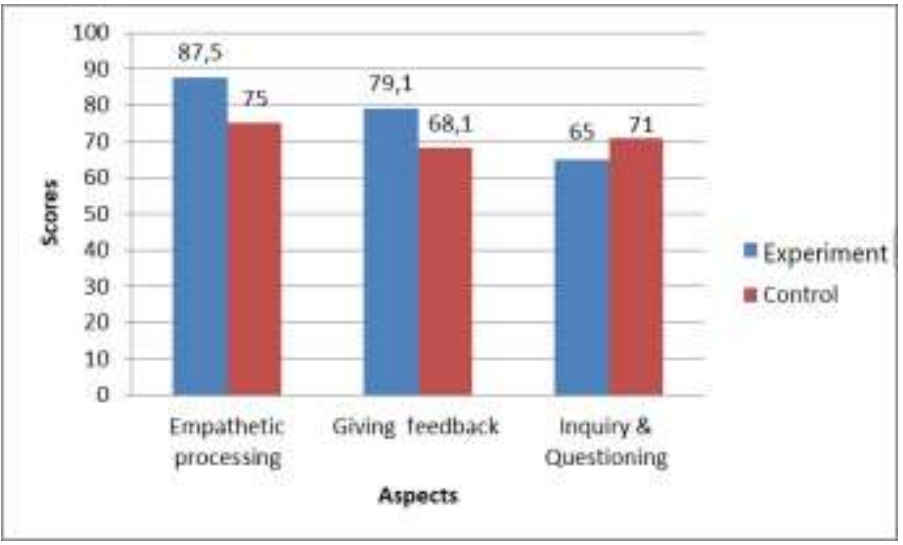

Figure 4. Graph of percentage values of each indicator of interpersonal intelligence

Figure 4 shows a graph of the percentage value of each indicator of students' interpersonal intelligence in the experimental class and the control class. The percentage of the innovative class and control class indicator values shows that the greatest value of students' interpersonal intelligence is empathetic processing. The lowest indicator value in the experimental class is shown in inquiry \& questioning, while in the control class, the lowest indicator is shown in giving feedback. The record of interpersonal intelligence in both classes is described in the following recap data Table 4.

Table 4. Analysis of interpersonal intelligence data

\begin{tabular}{|c|c|c|c|c|}
\hline No & $\begin{array}{l}\text { Interpersonal } \\
\text { intelligence indicator }\end{array}$ & Cognitive level taxonomy & $\begin{array}{l}\text { Experimentation } \\
\text { class }\end{array}$ & $\begin{array}{l}\text { Control } \\
\text { class }\end{array}$ \\
\hline \multirow[t]{3}{*}{1} & $\begin{array}{l}\text { Empathetic } \\
\text { processing }\end{array}$ & $\begin{array}{l}\text { Speak well from a partner's perspective, try to judge, } \\
\text { change, or broaden the partner's response. }\end{array}$ & 87.5 & 70.8 \\
\hline & & $\begin{array}{l}\text { Communicate partner's answers / responses, and } \\
\text { include the partner's perspective for accuracy. }\end{array}$ & 83.3 & 83.3 \\
\hline & & Accurately repeat answers / responses given by partners & 91.6 & 70.8 \\
\hline \multirow[t]{3}{*}{2} & Giving feedback & $\begin{array}{l}\text { Provide feedback through genuine dialogue with team } \\
\text { members where responses are explored and } \\
\text { investigated for a thorough understanding. }\end{array}$ & 83.3 & 66.7 \\
\hline & & $\begin{array}{l}\text { When giving feedback, ask team members to broaden } \\
\text { and clarify initial responses / answers. }\end{array}$ & 79.1 & 75.0 \\
\hline & & $\begin{array}{l}\text { Linking feedback and evaluating information whether it } \\
\text { matches the initial information. }\end{array}$ & 75.0 & 62.5 \\
\hline \multirow[t]{4}{*}{3} & Inquiry \& questioning & $\begin{array}{l}\text { Identify accurate responses by asking questions to } \\
\text { ensure that those who answer really understand the } \\
\text { concept. }\end{array}$ & 62.5 & 66.7 \\
\hline & & $\begin{array}{l}\text { Recognize accurate responses to questions even when } \\
\text { responses are said / spoken differently from the original } \\
\text { concept. }\end{array}$ & 66.7 & 75.0 \\
\hline & & Average & 78.6 & 71.4 \\
\hline & & Category & Competent & Competent \\
\hline
\end{tabular}

Based on the data in Table 4 above, it is concluded that the average number of interpersonal intelligence of the experimental class students is 78.6 and in the control class is 71.4 in which both are in the competent category. Meanwhile, the interpersonal intelligence test results obtained the highest score in the experimental class and control class that is in the first indicator of the process of someone responding to something (empathetic processing) on sub-indicators accurately repeating answers/responses given by partners 91.6 , whereas in the control class, on sub-indicator of communicating partner's answers/responses, and includes partner perspectives for accuracy is 83.3. While the lowest indicator value in the experimental class is found in indicator number 3 which is finding the answers and questions (inquiry \& questioning) sub-indicator identify 
accurate responses by questioning to ensure that the answer truly understands the concept of 62.5 but differs in the lowest indicator control class at no. 2 on the sub-indicator linking feedback and evaluating information whether it matches the initial information 62.5.

The difference in the increase in the interpersonal intelligence of the experimental class and control class students can be known by conducting statistical tests. The statistical test used in this study was carried out through two stages, including the prerequisite test and the different tests. The prerequisite test consists of a normality test conducted with the Kolmogorov test and a homogeneity test. The series of statistical tests in this study were carried out using SPSS 16 software.

Statistical tests were performed to determine differences in the interpersonal intelligence of the experimental class and control class students. The prerequisite test results for differences in interpersonal intelligence of the experimental class and control class students are explained in Table 5.

Table 5. Prerequisite test result

\begin{tabular}{lllll}
\hline \multirow{2}{*}{ Class } & \multicolumn{2}{c}{ Normality test } & \multicolumn{2}{c}{ Homogeneity Test } \\
\cline { 2 - 5 } & Sig. & Information & Sig. & Information \\
\hline Experiment & 0.99 & Normal & 0.585 & Homogen \\
Control & 0.98 & Normal & & \\
\hline
\end{tabular}

Based on the results of the normality test, it can be concluded that the experimental and control classes are normally distributed. Homogeneity test results show homogeneous data because of the value of sig. $0.585>0.05$. Based on the prerequisite test results, it is known that the data are normally distributed and homogeneous.

Significant values in the paired sample test showed $0.001<0.05$, which means that Ho was rejected, so it was concluded that there were differences in interpersonal intelligence between the experimental classes using the guided inquiry learning model and control classes that did not use guided inquiry learning model. Thus, it can be concluded that the interpersonal intelligence of the experimental class is more competent than the control class.

Based on these data, it can be concluded that the guided inquiry learning model can improve students' interpersonal intelligence. According to (Berrocal, Extremera, Lopes, \& Aranda, 2014) states that the guided inquiry learning model can train students' interpersonal intelligence with satisfactory results. According to (Freudenthaler \& Neubauer, 2005) added that the guided inquiry learning model could train multiple intelligences so as to improve students' interpersonal intelligence abilities.

Based on the interpersonal intelligence results data, there are the highest and lowest indicators. The highest indicator obtained by the experimental class and the control class is the first indicator, which is the process of someone responding to something (Empathetic processing). Every indicator of students' interpersonal intelligence is combined with cognitive taxonomy so that each indicator has a sub-indicator of the students' cognitive abilities. The first indicator is a sub-indicator; the first sub-indicator is to speak well from the perspective of partners, try to assess, change, or expand partner responses. The second subindicator is communicating the partner's answer/response and includes the partner's perspective for its accuracy, while the last sub-indicator is to repeat the answer/response given by the partner accurately.

The final sub-indicator of the Empathetic processing indicator is speaking well from the perspective of partners, trying to assess, change or expand partner responses with the results of the experimental class superior to the control class because the ability of active students to help identify group goals and work hard to achieve these goals for example in the process student learning is very empathetic with friends in one group. In this process of visible student activity during group discussions, students who do not understand the learning material by themselves can be helped by the other friends who explain the material. In addition, students who have not yet found an answer from the results of the experiment will be guided by other friends because it emphasizes the achievement of shared learning goals, and the students ask friends for help with good sentences and thanks. This is in line with Liu, Xu, Xiao, Liu, and Li (2020) which states that discussion stimulates students' courage and creativity in expressing ideas, getting in the habit of exchanging ideas, and respecting the opinions of others.

The lowest indicator of interpersonal intelligence is the third indicator finding answers and questions (Inquiry and Questioning). There are two sub-indicators; the first is the sub-indicator of identifying an accurate response by asking questions to make sure that the answer is truly related to the concept. While in the experimental class, students have not been able to elaborate on some of the questions of the problems faced by the sub-material of the influence of smoking on health or respiratory frequency so that students have difficulty finding answers to a question. Moreover, the reason is that students are less creative in expressing 
opinions related to learning topics that support abilities or self-potential, which indicates that they have not been able to express the results of what they report. That interpersonal intelligence arises when someone is able to establish social relationships with others and be able to respond appropriately (Luijk et al., 2019; Metcalf et al., 2018; Murphy \& Hall, 2011; Wang \& Jou, 2016).

The second sub-indicator is recognizing the accurate response to the question even when the response is said/pronounced differently from the original concept. At this stage, the acquisition of the control class is greater than the experimental class. This is due to the ability of students in the learning process. The control class can understand the questions raised by friends with understanding in the presentation activities and can convey information clearly that they find and focus on the content of the subject matter content. On the other hand, in the control class, the participation of students in responding to their peers at the time of reporting is very conducive where other students will respond to the results of the group's presentation if there is a material that is not original.

Based on the explanation above, it is proven empirically and theoretically that students who study with the guided inquiry learning model on the sub-material of the influence of cigarettes on health and respiratory frequency experience a more significant increase in interpersonal intelligence than students who do not use guided inquiry learning models.

The student questionnaire is used to determine student responses to the use of the guided inquiry learning model. The questionnaire was filled out at the end of the learning process. The questionnaire was given to students who were included in the experimental class with the aim of knowing students' responses to the use of the guided inquiry learning model. Based on the results of the questionnaire analysis of student responses to learning with the guided inquiry learning model that has been done, it shows that class students give positive responses based on the results of questionnaire filling data. The results of the questionnaire analysis in the form of a questionnaire percentage can be seen in Figure 5 (Indicator 1 is implementation, Indicator 2 is learning process, and Indicator 3 is evaluation).

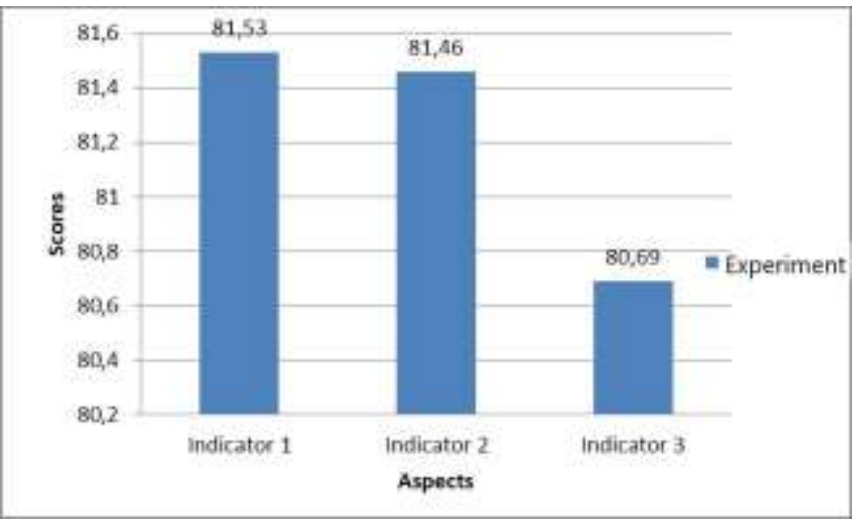

Figure 5. Graph of student response recapitulation results

Figure 5 shows the results of the recapitulation of student responses to each indicator containing statements given to the guided inquiry learning model on the concept of the respiratory system in humans. Based on the data above, the acquisition of the highest indicator is the first indicator of 81.53. This means that the application of the guided inquiry learning model provides a very good response for students with student abilities that arise. The students ask lots of questions and gradually answer questions raised by their friends and can solve the problem. Meanwhile, the lowest indicator is the last indicator in which the score is 80.69 . This is because students are still not correct in determining the conclusions of learning that have been done so that the evaluation of the learning process material is low.

Positive responses given by students to learning by using the guided inquiry learning model provide new experiences that they receive in the classroom learning atmosphere, so as to create comfortable and effective learning. Students can also feel that learning is very different from the daily learning process, so they are more enthusiastic about learning, especially learning that requires them to directly observe a series of data collection activities through observation by prioritizing scientific methods based on evidence from observable, empirical and measurable objects with specific principles of reasoning (Gillies \& Rafter, 2020; Jerrim et al., 2019; Yudarwati, 2019). 


\section{CONCLUSION}

Implementation using the guided inquiry learning model shows that the teacher is able to carry out the learning process in class with excellent categories. This is marked by the teacher being able to carry out all the stages in the implementation of the guided inquiry learning model. The use of the guided inquiry learning model can improve students' science process abilities and interpersonal intelligence.

\section{ACKNOWLEDGMENT}

Thank you to my parents, husband and beloved children and all of the Jamblang family and Kertasura family, and don't forget the academic advisor who always directs this research.

\section{REFERENCES}

Abungu, H. E., Okere, M. I. O., \& Wachanga, S. W. (2014). The effect of science process skills teaching approach on secondary school students' achievement in chemistry in Nyando District, Kenya. Journal of Educational and Social Research, 4(6), 359-372. doi: https://doi.org/10.5901/jesr.2014.v4n6p359

Berrocal, P. F., Extremera, N., Lopes, P. N., \& Aranda, D. R. (2014). When to cooperate and when to compete: Emotional intelligence in interpersonal decision-making. Journal of Research in Personality, 49, 21-24. doi: https://doi.org/10.1016/j.jpp.2013.12.005

Birren, J. M., \& Kieboom, L. A. V. D. (2017). Exploring the development of core teaching practices in the context of inquiry-based science instruction: an interpretive case study. Teaching and Teacher Education, 66, 74-87. doi: https://doi.org/10.1016/j.tate.2017.04.001

Connors, P. (2019). Guided inquiry-based learning and the date label/milk waste conundrum. Journal of Nutrition Education and Behavior, 51(7), 79-85. doi: https://doi.org/10.1016/j.jneb.2019.05.480

Cotton, J. A. (2009). Guided inquiry: learning in the 21st century. The Journal of Academic Librarianship, 35(1), 102-110. doi: https://doi.org/10.1016/j.acalib.2008.10.012

Ebert, L., Mollart, L., Nolan, S. J., \& Jefford, E. (2020). Nurses and midwives teaching in the academic environment: An appreciative inquiry. Nurse Education Today, 84, 1-10. doi: https://doi.org/10.1016/j.ne dt.2019.104263

Eskin, H., \& Bekiroglu, F. O. (2013). Argumentation as a strategy for conceptual learning of dynamics. Research of Science Education, 43(5), 1939-1956. doi: https://doi.org/10.1007/s11165-012-9339-5

Freudenthaler, H. H., \& Neubauer, A. C. (2005). Emotional intelligence: the convergent and discriminant validities of intra- and interpersonal emotional abilities. Personality and Individual Differences, 39(3), 569-579. doi: https://doi.org/10.1016/j.paid.2005.02.004

Gillies, R. M., \& Rafter, M. (2020). Using visual, embodied, and language representations to teach the 5E instructional model of inquiry science. Teaching and Teacher Education, 87, 1-10. doi: https://doi.org/10 .1016/j.tate.2019.102951

Hindriana, F. A. (2016). The development of biology practicum learning based on vee diagram for reducing student cognitive load. Journal of Education, Teaching and Learning, 1(2), 61-65. doi: https://doi.org/10. 26737/jetl.v1i2.39

Hong, J. C., Tsai, C. R., Hsiao, H. S., Chen, P. H., Chu, K. C., Gu, J., \& Sitthiworachart, J. (2019). The effect of the "prediction-observation-quiz-explanation" inquiry-based e-learning model on flow experience in green energy learning. Computers \& Education, 133, 127-138. doi: https://doi.org/10.1016/j.compedu.2 019.01.009

Jerrim, J., Oliver, M., \& Sims, S. (2019). The relationship between inquiry-based teaching and students' achievement. New evidence from a longitudinal PISA study in England. Learning and Instruction, 61, 35-44. doi: https://doi.org/10.1016/j.learninstruc.2018.12.004

Lawless, K. A., Brown, S. W., Rhoads, C., Lynn, L., \& Newton, S. D. (2018). Promoting students' science literacy skills through a simulation of international negotiations: the globaled 2 project. Computers in Human Behavior, 78, 389-396. doi: https://doi.org/10.1016/j.chb.2017.08.027

Linnell, J., Brian, K., Scherr, R., Nicholson, Y., Spezzano, T., Smith, M. H., \& Cherr, S. Z. (2013). Using lesson artifacts to evaluate acquisition of nutrition terms and concepts and development of science process skills. Journal of Nutrition Education and Behavior, 45(4), 38-45. doi: https://doi.org/10.1016/ j.jneb.2013.04.102 
Liu, L., Xu, L., Xiao, X., Liu, L., \& Li, Y. (2020). Positive influence of peers' interpersonal character on children's interpersonal character: The moderating role of children's and peers' social status. Journal of Adolescence, 79, 157-172. doi: https://doi.org/10.1016/j.adolescence.2020.01.003

Luijk, L. U., Kruger, M., Zijlstra, B., \& Volman, M. (2019). Teachers' role in stimulating students' inquiry habit of mind in primary schools. Teaching and Teacher Education, 86, 1-10. doi: https://doi.org/10.1016/j.ta te.2019.102894

Makar, K., Ali, M., \& Fry, K. (2018). Narrative and inquiry as a basis for a design framework to reconnect mathematics curriculum with students. International Journal of Educational Research, 92, 188-198. doi: https://doi.org/10.1016/j.ijer.2018.09.021

Metcalf, S. J., Reilly, J. M., Kamarainen, A. M., King, J., Grotzer, T. A., \& Dede, C. (2018). Supports for deeper learning of inquiry-based ecosystem science in virtual environments - Comparing virtual and physical concept mapping. Computers in Human Behavior, 87, 459-469. doi: https://doi.org/10.1016/j. chb.2018.03.018

Michos, K., \& Leo, D. H. (2020). CIDA: A collective inquiry framework to study and support teachers as designers in technological environments. Computers \& Education, 143, 1-10. doi: https://doi.org/10.101 6/j.compedu.2019.103679

Murphy, N. A., \& Hall, J. A. (2011). Intelligence and interpersonal sensitivity: A meta-analysis. Intelligence, 39(1), 54-63. doi: https://doi.org/10.1016/j.intell.2010.10.001

Nenadal, L., \& Mistry, R. S. (2018). Teacher reflections on using inquiry-based instruction to engage young children in conversations about wealth and poverty. Early Childhood Research Quarterly, 42, 44-54. doi: https://doi.org/10.1016/j.ecresq.2017.07.008

Rey, L., \& Extremera, N. (2014). Positive psychological characteristics and interpersonal forgiveness: identifying the unique contribution of emotional intelligence abilities, big five traits, gratitude and optimism. Personality and Individual Differences, 68, 199-204. doi: https://doi.org/10.1016/j.paid.2014.0 4.030

Roller, M. C., \& Zori, S. (2017). The impact of instituting process-oriented guided-inquiry learning (POGIL) in a fundamental nursing course. Nurse Education Today, 50, 72-76. doi: https://doi.org/10.1016/j.nedt.2016 .12 .003

Romero, N. A. R., Berrocal, P. F., Estrada, J. G. S., \& Guajardo, J. G. (2017). Positive emotions, self-esteem, interpersonal relationships and social support as mediators between emotional intelligence and life satisfaction. Journal of Behavior, Health \& Social Issues, 9(1), 1-6. doi: https://doi.org/10.1016/j.jbhsi.20 17.08 .001

Stouwe, T. V. D., Asscher, J. J., Hoeve, M., Laan, P. H. V. D., \& Stams, G. J. J. M. (2018). Social skills training (SST) effects on social information processing skills in justice-involved adolescents: Affective empathy as predictor or moderator. Children and Youth Services Review, 90, 1-7. doi: https://doi.org/ 10.1016/j.childyouth.2018.05.006

Teig, N., Scherer, R., \& Nilsen, T. (2018). More isn't always better: the curvilinear relationship between inquiry-based teaching and student achievement in science. Learning and Instruction, 56, 20-29. doi: https://doi.org/10.1016/j.learninstruc.2018.02.006

Ucar, S., \& Trundle, K. C. (2011). Conducting guided inquiry in science classes using authentic, archived, web-based data. Computers \& Education, 57(2), 1571-1582. doi: https://doi.org/10.1016/j.compedu.201 1.02 .007

Wang, J., \& Jou, M. (2016). Qualitative investigation on the views of inquiry teaching based upon the cloud learning environment of high school physics teachers from Beijing, Taipei, and Chicago. Computers in Human Behavior, 60, 212-222. doi: https://doi.org/10.1016/j.chb.2016.02.003

Wen, C. T., Liu, C. C., Chang, H. Y., Chang, C. J., Chang, M. H., Chiang, S. H., \& Hwang, F. K. (2020). Students' guided inquiry with simulation and its relation to school science achievement and scientific literacy. Computers \& Education, 149, 1-10. doi: https://doi.org/10.1016/j.compedu.2020.103830

Yudarwati, G. A. (2019). Appreciative inquiry for community engagement in Indonesia rural communities. Public Relations Review, 45(4), 1-10. doi: https://doi.org/10.1016/j.pubrev.2019.101833

Zhang, L. (2019). "Hands-on" plus "inquiry"? Effects of withholding answers coupled with physical manipulations on students' learning of energy-related science concepts. Learning and Instruction, 60, 199-205. doi: https://doi.org/10.1016/j.learninstruc.2018.01.001 